\title{
ГЕОЛОГИЧЕСКОЕ РАЗВИТИЕ ОЗЕРА ТЯНАВЪЯРВ
}

Прибрежные озера на разновозрастных террасах Балтийского моря составляют примерно 15-17\% от общего количества озер Эстонии. Их число постоянно изменяется из-за образования новых путем отделения от моря лагун, исчезновения после заболачивания и осушения. Наиболее древними среди прибрежных являются озера, расположенные выше максимальной линии Анцилового озера (озера Кахала, Каруярв, Пелисоо и др.). Количество озер на террасах Литоринового моря невелико. Стратиграфия озер этого типа - Клоога, Мяннамаа (Тиху) и Энгламаа, была изучена П. Томсоном (Thomson, 1929). В настоящее время исследован ряд лагун в окрестностях с. Ныва (Kessel, Orviku, 1969), авторами изучены донные отложения оз. Тянавъярв и болото Вески в СевероЗападной Эстонии и оз. Охтья на о-ве Сааремаа. Продолжаются исследования на озерах Тиху.

В данной статье предлагается материал, полученный при изучении о3. Тянавъярв и болота Вески (часть болота Ляянемаа Суурсоо), расположенных южнее с. Ныва. Здесь находятся две группы озер. К первой относятся небольшие зарастающие озера на террасе Лимниевого моря, которые отделились от моря в поздней субатлантике менее чем 1000 л. н. Они расположены среди прибрежных мечтравовых болот (Мяэметс, 1984). Впадины озер практически лишены донных отложений. Вторую группу составляют озера Хиндасте, Вескиярв и Тянавъярв, которые сходны по морфометрическим показателям, но значительно различаются по физико-химическим свойствам воды, флоре и фауне.

В озерах Тянавъярв и Вескиярв растет Lobelia dortmanna - единственное современное нахождение в Западной Эстонии (Мяэметс, 1984). Этот редкий бореоатлантический вид, включенный в Красную книгу Эстонии (Punane raamat, 1982), встречается вблизи юго-восточной границы своего биогеографического ареала. Вместе с другим редким видом, Isoëtis lacustris, малочисленная популяция которого обнаружена здесь в 1981 г., они являются индикаторами олиготрофных озер, которые в Эстонии стали уже редкостью. Следует подчеркнуть, что Isoëtis lacustris содействует омоложению определений радиоуглеродного возраста (Kaland, 1984). Третим редким растением в оз. Тянавъярв является Sparganium gramineum. Этот вид тоже обитатель мягководных олиготрофных озер и также включен в Красную книгу Эстонии (Punane raamat, 1982). Учитывая произрастание такой уникальной водной растительности, наши биологи предложили взять оз. Тянавъярв под охрану (Мяэметс, 1984).

\section{Общая характеристика}

Оз. Тянавъярв расположено на флювиогляциальной дельте Вескиярв, севернее максимальной границы краевых ледниковых образований паливереской стадии, возраст которой примерно 11200 лет (Серебрянный, Раукас, 1966). Дегляциация в окрестностях Ныва произошла примерно 11100 л. н., самостоятельное развитие озера началось в конце атлантического периода, после освобождения данного района из-под вод Литоринового моря, 


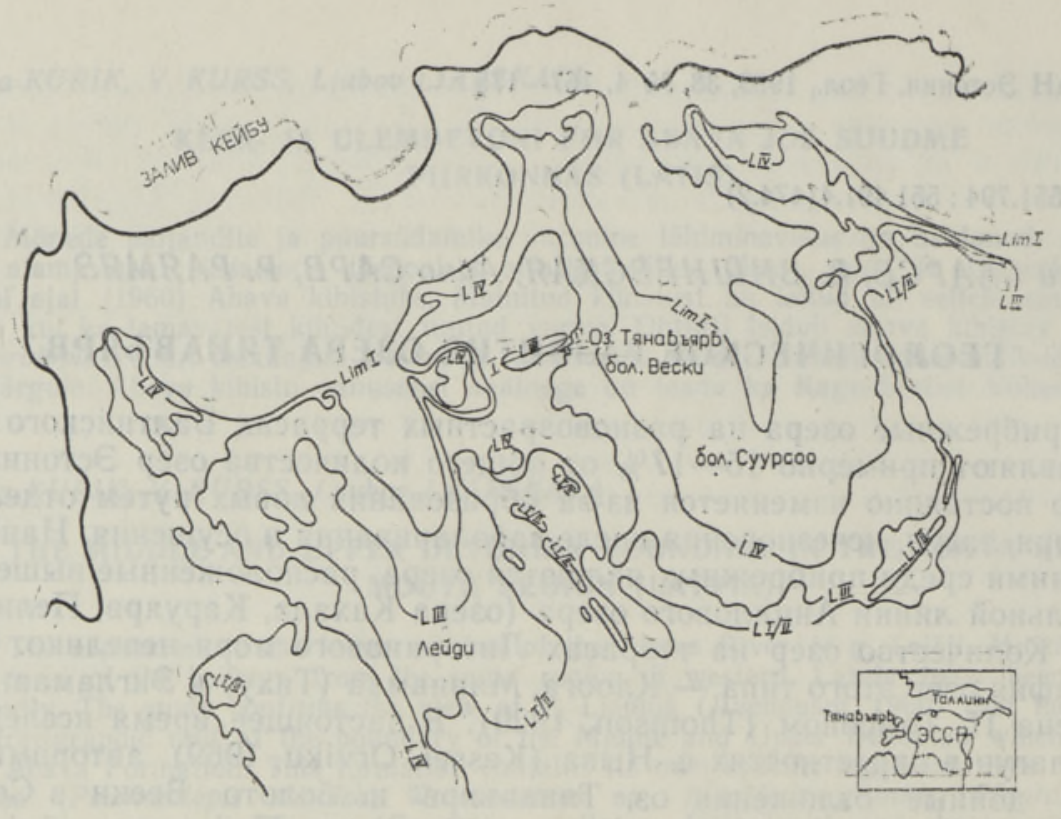

Рис. 1. Расположение оз. Тянавъярв и болота Вески с указанием местоположения геологического разреза и береговых линий по X. Кессел. L - береговые линии Литоринового моря; Lim - береговые линни Лимниевого моря.

Оз. Тянавъярв расположено в 9 км к юго-востоку от залива Кейбу (рис. 1) на абсолютной высоте 18,4 м. Крупное мелководное озеро (плющадь 136,9 га, максимальная глубина 2,5 м, средняя 1,8 м) продолговатое, ориентировано с северо-востока на юго-запад. Длина озера 2300 м, ширина 830 м, берега извилистые, местами песчанистые, обрамленные сосновыми борами. Атмосферные осадки и грунтовые воды обеспечивают питание озера и временный сток в оз. Вескиярв. В озерной воде содержится мало минеральных $\left(\mathrm{HCO}^{-}{ }_{3} 12-24\right.$ мг/л, сумма ионов $37-41 \mathrm{мг} / л)$ и органических 'веществ $\left(19-33 \mathrm{mr} / \mathrm{I}^{\prime} \mathrm{O}_{2}\right)$ (Eesti järved, 1968). Водная растительность редкая и малоразвитая, покрывает только $20 \%$ дна озера. Среди макрофитов доминирует тростник с болотницей, осокой и хвощом (Мяэметс, 1984).

\section{Литология}

Примерно $70 \%$ дна оз. Тянавъярв покрыто маломощным тонкодетрнтовым органическим сапропелем, довольно однообразным по своему составу. Верхний слой накопившегося вдоль западного берега сапропеля грубодетритовый, под ним студенистый, сапропель, подстилающийся тонким слоем алеврита и песка. В остальных частях акватории сапропель !перекрывает пески. Его мощность наибольшая в западной части озера (до 2,3 м). К востоку органогенные отложения постепенно утончаются и 'выклиниваются в литоральной зоне озера (рис. 2). Скорость осадкообразования и темп прироста сапропеля здесь низкие, в среднем $0,28 \mathrm{mм} /$ год, что обусловлено олиготрофностью и малой биопродуктивностью озера. Антропогенная нагрузка на оз. Тянавъярв небольшая, так как озеро находится далеко от шоссейных дорог и деревень, окружено заболоченным лесом и верховым болотом. При средней мощности 0,5 м запасы сапропеля составляют $80000 \mathrm{~m}^{3}$. 


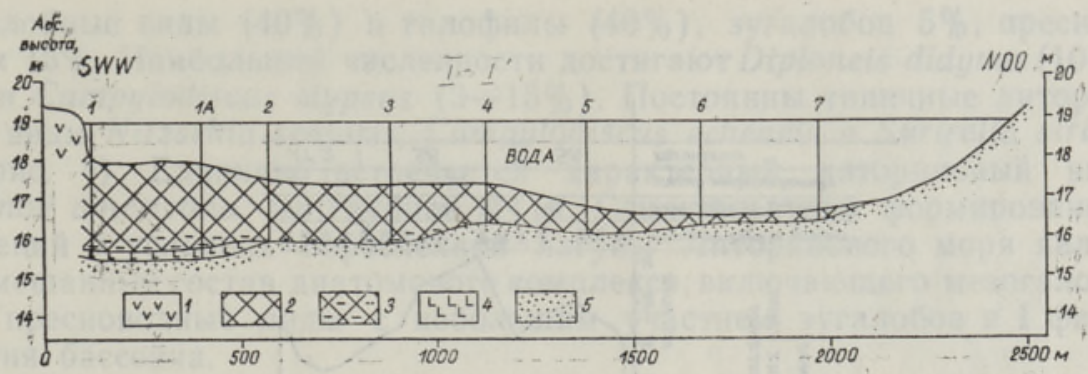

Рис. 2. Геологический разрез донных отложений оз. Тянавъярв. 1 - торф; $2-$ органический сапропель; 3 - кремнеземистый сапропель; 4 - алеврит; 5 - песок.

Сапропель оз. Тянавъярв, как и всех других олиготрофных озер Эстонии отличается высоким содержанием органического вещества $(70-76 \%)$ и низким - карбонатов (кальцита $1,75-1,98 \%$, доломита $1,09-2,22 \%)$. В минеральном составе превалирует кварц с примесями полевых шпатов, гидрослюд, хлоритов, доломита, кальцита и пирита. Содержание органического вещества в основании разреза резко понижается до $16 \%$. Преобладает терригенный компонент с таким же содержанием карбонатов, как в органическом сапропеле. Сапропелевый алеврит (ил) содержит до $14 \%$ органического вещества и почти в 4 раза больше доломита $(5,50 \%)$, чем вмещающий кремнеземистый сапропель. Карбонаты здесь явно аллотигенного происхождения.

\section{Биостратиграфия}

Мелкозернистый песок и алеврит с растительным детритом на глу. бине $3,2-3,6$ м содержат пыльцу широколиственных до $14 \%$, ольхи $28-$ $30 \%$, березы $30-35 \%$, ели $3-4 \%$ (рис. 3). Такой пыльцевой комплекс соответствует позднеатлантической хронозоне. Диатомовая флора на этой глубине представлена смешанным составом. Преобладают морские
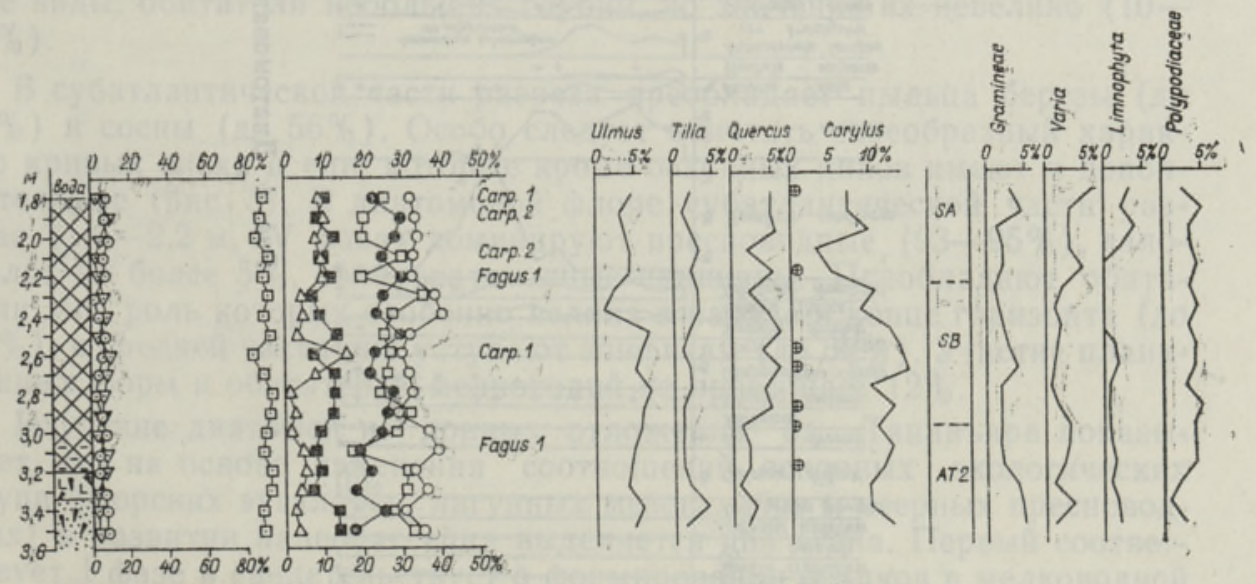

$\triangle X_{1} \alpha_{2}$

Рис. 3. Спорово-пыльцевая диаграмма донных отложений оз. Тянавъярв (скв. 9), 1 сапропель, 2 - кремнеземнстый сапропель, 3 - алеврит с органическим детритом; 4 песок с органическим детрнтом, 5- пыльца сосны, 6 - ели, 7 - березы, 8 - ольхн, 9 - широколиственных пород. 10 - ивы, 1,1 - древесных пород, 12 - травянистых, 13 - споры. 


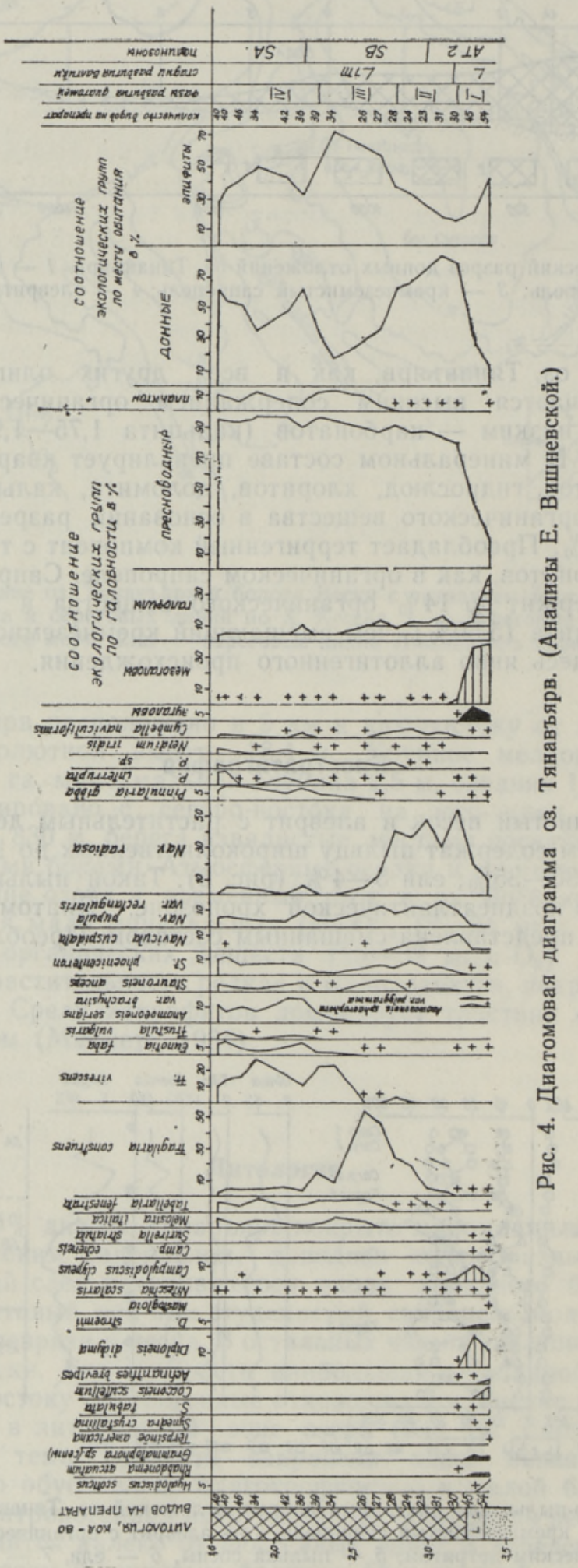


мезогалобные виды $(40 \%)$ и галофилы $(40 \%)$, эугалобов 5\%, пресноводных $15 \%$. Наибольшей численности достигают Diploneis didyma (10$20 \%$ ) и Campylodiscus clypeus (3-15\%). Постоянны типичные литориновые виды Nitzschia scalaris, Campylodiscus echeneis и Surirella striatula (рис. 4). Единично встречается характерный литориновый вид Terpsinoё americana на глубине 3,4 м. Свидетельством формирования отложений в условиях опресненной лагуны Литоринового моря является смешанный состав диатомового комплекса, включающего мезогалобные и пресноводные виды с небольшим участием эугалобов в I фазе развития бассейна.

Содержание пыльцы широколиственных пород в залегающем выше кремнеземистом сапропеле на глубине 2,8-3,2 м остается еще сравнительно высоким $(10 \%)$. Содержание пыльцы ели, наоборот, низкое, а пыльцы дуба не достигла еще своего максимума. Такие палиноспектры характерны отложениям поздней атлантики и раннему суббореалу.

В составе диатомовых произошли существенные изменения. В интервале 2,8-3,2 м резко возросла роль пресноводных видов (85-$90 \%)$, участие галофилов снизилось до $15 \%$. Солоноватоводных менее $1 \%$, среди них постоянны Campylodiscus clypeus и фрагменты Nitzschia scalaris. Преобладают обитатели пелогена (дна) $(60-83 \%)$, представленные разнообразными видами рода Navicula, причем кривая процентного содержания донных видов снижается вверх по разрезу, значение эпифитов возрастает снизу вверх от 15 до $37 \%$.

В отложениях суббореала показательно участие пыльцы ели до $20 \%$ (рис. 3,5$)$. При сравнении диаграмм отложений близлежащих болот выявляются четкие различия, указывающие на дифференциацию растительности. Так, например, во второй половине суббореального времени в районе оз. Тянавъярв последовательно доминировали береза, ольха, сосна (рис. 3), в районе болот Арусте и Вески - сосна, береза и ольха (рис. 4), болота Энгламаа - сосна, береза, ольха (Kessel, Orviku, 1969).

В диатомовой флоре интервалом 2,3-2,8 м (III фаза) преобладают пресноводные виды $(87-95 \%)$, галофилов 5-10\%, солоноватоводные единичны. Доминируют эпифиты $(60-70 \%)$, среди них Fragilaria construens составляет до $55 \%$. Кривая содержания донных видов снижается от 40 до $18 \%$ и вновь возрастает до $30 \%$. Появляются планктонные виды, обитатели небольших глубин, но значение их невелико (10$13 \%)$.

В субатлантической части разреза преобладает пыльца березы (до $48 \%$ ) и сосны (до $56 \%$ ). Особо следует отметить своеобразный характер кривых ольхи и ели, которые кроме основных пиков имеют и дополнительные (рис. 5). В диатомовой флоре субатлантической части разреза $(1,6-2,2$ м, IV фаза) доминируют пресноводные $(93-95 \%)$, галофилов не более $5 \%$, солоноватоводные единичны. Преобладают обитатели дна, роль которых особенно велика в начале и конце горизонта (до $62 \%$ ), в средней части они уступают эпифитам (до $50 \%$ ). Участие планктонных форм и обитателей мелководий не превышает $12 \%$.

Изучение диатомей из донных отложений оз. Тянавъярв показывает, что на основе изменения соотношений основных экологических групп (морских эугалобов, лагунных мезогалобов и озерных пресноводных) в развитии палеобассейна выделяется два этапа. Первый соответствует I фазе и свидетельствует о формировании осадков в мелководной опресненной лагуне Литоринового моря; второй представлен II-IV фазами, в течение которых осадки накапливались в неглубоком пресном водоеме. Снижение роли эпифитов в II и IV фазе указывает на более высокий уровень водоема и меньшее его зарастание в эти периоды. Если эти данные сравнить со средней кривой изменения уровня воды Эстонии (Saarse, 1987), то в общих чертах они совпадают. В озерах Эстонии 

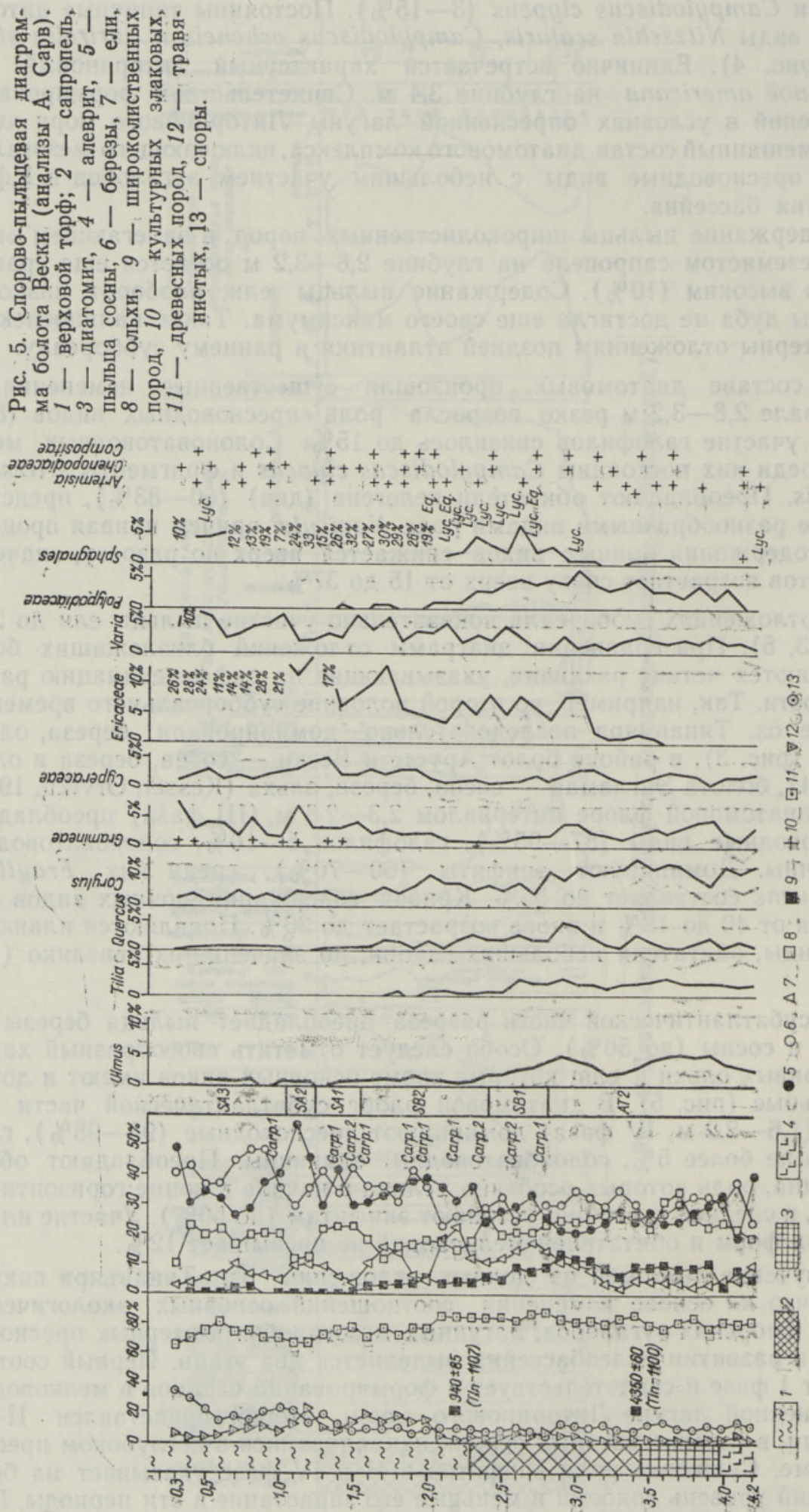
о̆тмечается понижение уровня воды в позднем суббореале, повышение в раннем суббореале и в субатлантическом периоде. В данном случае изменению уровня воды способствовали еще локальные факторы понижение уровня грунтовой воды в связи с неотектоническим подня тием земной коры и регрессия Балтийского моря.

Изучение спорово-пыльцевого состава донных отложений озер и болот окрестности Ныва показывает, что палинологические диаграммы данного района трудно интерпретируются, а все ${ }^{14} \mathrm{C}$-датировки, видимо, моложе действительных. Примером можно привести разрез Вахару (Сарв, Ильвес, 1971), где граница SA1/SA2 на 270 лет моложе, чем это указано в стратиграфической схеме Эстонии (Каяк и др., 1976), возраст граница SA1/SB2 моложе на 320 лет, SB2/SB1 - на 450 лет, SB1/AT2 на 650 лет и АT2/AT1 - на 840 лет.

Полученный нами возраст контакта лагунных и озерных отложений на $600-800$ лет моложе, чем можно было ожидать по данным развития Балтийского моря (Kessel, Raukas, 1979). В приведенном выше случае ${ }^{14} \mathrm{C}$-анализу подвергались весьма разнотипные отложения - верховой и низинный торф, малоконсолидированный и плотный сапропель. На эту проблему в Эстонии до последнего времени не обращали должного внимания. На расхождение результатов палинологических и ${ }^{14} \mathrm{C}$-анализов при изучении торфяных массивов обращали внимание Г. А. Елина (1981), К. Е. Иванов и Г. И. Клейменова (1984) и др. В качестве основного фактора ими отмечается движение воды в болотах от центра массива к его периферии. Этим объясняется вынос растворимых продуктов разложения растительного покрова более поздних периодов и омолаживание тем самым возраста периферийных отложений торфяного массива (Иванов, Клейменова, 1984). Правильность такого объяснения в данном случае сомнительна.

\section{Развитие оз. Тянавъярв}

Резкое изменение состава диатомовой флоры на глубине 3,2 м показывает, что на этом уровне произошло отделение оз. Тянавъярв от моря. В данном случае это хорошо маркировано седиментационным контактом алеврита и сапропеля. Известно, что уровень Литоринового моря в данном районе во время I и II стадий развития находился на абсолютной высоте 21 м, береговые валы и бары III фазы близ Арусте - на высоте 16,6 м (Kessel, Orviku, 1969). Реконструкция береговой линии данных стадий показывает, что во время трансгрессивных фаз Литоринового моря (LI/LII) образовались лагуны Суурсоо (окруженные полукруглым баром Куййыэ) (Кессел, Раукас, 1967) и Лейдисоо с полуостровом Вески между ними (рис. 1). В ходе последующей регрессии Литоринового моря и неотектонического поднятия земной коры впадины озер Тянавъярв и Хиндасте изолировались, что могло происходить примерно $5300-5000$ л. н. до или во время III фазы Литоринового моря. После этого водоем продолжил свое самостоятельное развитие в качестве олиготрофного бассейна.

\section{Основные выводы}

До последннего времени в Северо-Западной Әстонии отсутствовали детально изученные голоценовые озерно-болотные разрезы. На более ранних палинологических диаграммах не представлены элементы травянистых - отражены лишь спектры древесных. Данные о диатомовой флоре тоже весьма фрагментарны. Поэтому, планируя систематическое исследование озер в рамках проекта № 158 МПГК мы выбрали оз. Тянавъ- 
ярв в качестве вторичного ключевого разреза в понимании Б. Ә. Берглунда (Berglund, 1983). Этому способствовала уникальность водной растительности данного озера (Мяэметс, 1984).

Геологические исследования позволили выяснить, что состав донных отложений олиготрофных озер весьма однообразен и характеризуется высоким содержанием органического вещества и низким - карбонатного компонента. Темп прироста сапропеля замедленный - в среднем 0,28 мм/год. Донные отложения оз. Тянавъярв оказались трудно стратифицированными палинологически, поэтому нами изучался еще дополнительный разрез в болоте Вески, примерно 50 м северо-восточнее озера. В болотных отложениях выяснился факт несоответствия данных палинологического анализа и ${ }^{14} \mathrm{C}$-метода. Полученные радиоуглеродные датировки здесь и в других разрезах данного района (Энгламаа, Вахару) оказались омоложенными, причиной этому может быть своеобразие гидрологического режима верховых болот, а также общегеологические факторы, как неотектоническое поднятие земной коры, что в конечном итоге является причиной изменения уровня грунтовых вод. Но эта ғроблема требует проведения дополнительных исследований.

По возрасту и абсолютной отметке контакта между морскими и озерными отложениями нами вычислена средняя скорость поднятия земной коры в данном районе. Это, по нашим калькуляциям, составляет с конца атлантики в среднем 2,1 мм/год. По палинологическим данным озеро Тянавъярв отделилось от моря в конце атлантического периода, что подтверждается и сменой комплекса морских мезогалобных и галофильных диатомей на пресноводный.

Авторы статьи выражают благодарность проф. А. Раукасу за ценные советы, признательность А. Ронк за оформление рисунков и К. Киммель за помощь в полевых работах.

\section{ЛИТЕРАТУ РА}

Елина $Г$. А. Принципы и методы реконструкции и картировання растительности голоцена. Л., 1981.

Иванов K. Е., Клейменова Г. И. Сравнение палинологического и радиоуглеродного методов при изучении стратиграфии торфяной залежи // Проблемы современной палинологии. Новосибирск, 1984, 65-67.

Каяк K., Кессел Х., Лийвранд Э. и др. Местная рабочая стратиграфическая схема четвертичных отложеннй Эстонии // Стратиграфия четвертичных отложений Прибалтики. Вильнюс, 1976, 4-42.

Кессел Х. Я., Раукас А. В. Прибрежные отложения Анцилового озера и Литоринового моря в Әстонии. Таллинн, 1967.

Мяэметс А(йме). Озера окрестности с. Ныва // Водно-болотная флора и растнтельность. Путеводитель. Таллинн, 1984, 21-32.

Сарв А. А., Нльвес Э. О. Датирование по радиоуглероду озерно-болотных отложений бол. Вахару (Северо-Западная Эстония) // Палинологические исследования в Прибалтике. Рига, 1971, 143-149.

Серебрянный Л. Р., Раукас А. В. Трансбалтийские корреляции краевых ледниковых образований позднего плейстоцена // Верхний плейстоцен. Стратиграфия и абсолютная геохронология. M., 1966, 12-28.

Berglund, B. E. Palaeohydrological studies in lakes and mires - a palaeoecological research strategy // Background to palaeohydrology, 1983, 237-254.

Eesti järved. Tallinn, 1968.

Kaland, P. E. Holocene shore displacement and shorelines in Hordaland, western Norway // Boreas, 1984, 13, N 3, 203-245.

Kessel, H., Orviku, K. Läänemere regressiivsete setete geoloogiline ehitus ja areng Loode-Eestis. Käsikiri ENSV TA Keskarhiivis. Tallinn, 1969.

Kessel, H., Raukas, A. The Quanternary History of the Baltic. Estonia // The Quaternary History of the Baltic // Acta Univ. Ups. Symp. Univ. Ups. Ann. Quing. Cel., $1979,1,12 \dot{7}-146$. 
Punane raamat. Tallinn, 1982.

Saarse, L. The Holocene palaeoecological changes in Estonia // IGCP 158. Palaeohydrological changes in the temperate zone in the last 15000 years: Abstracts. Lundqua Report 27. Lund, 1987, 121-124.

Thomson, $P$. W. Die regionale Entwicklungsgeschichte der Wälder Estlands // Acta Univ. Tartuensis, 1929, 17.

\section{Институт геологии Академии наук Эстонской ССР \\ Поступила в редакцию $17 / \mathrm{X} 1988$}

\section{Ленинградский государственный университет}

Leili SAARSE, E. VISNEVSKAJA, Aino SARV, R. RAJAMAE

\section{TANAVJARVE GEOLOOGILINE ARENG}

On esitatud Tänavjärve lito- ja biostratigraafilise uurimise tulemused ning näidatud Veskisoo ja Vaharu raba andmete põhjal, et soosetete vanus ${ }^{14} \mathrm{C}$-analüüsi järgi ei vasta polünoloogilistele tulemustele; on analüüsitud selle nähtuse põhjusi ja antud Nõva ümbruse keskmine neotektoonilise kerke kiirus viimase 5000 aasta jooksul.

\section{Leili SAARSE, E. VISHNEVSKAYA, Aino SARV, R. RAJAMÄE}

\section{THE EVOLUTION OF LAKE TÄNAVJÄRV}

The authors present the results of litho- and biostratigraphic investigation of L. Tänavjärv, NW Estonia. It has been found that the lake was isolated from the Litorina Sea at the end of the Late Atlantic period. Since then fine-grained sand and silt with plant macroremnants, diatomite and organic gyitja have been accumulated. On the ground of pollen and spore diagrams it is complicated to establish the limits of chronozones. The radiocarbon datings of Vaharu and Veski peatbogs are younger than it is assumed on the basis of biostratigraphic material. One reason for this may be the infiltration of ground water from the central part of raised bogs to their edge and into the lake. The neotectonic uplift also causes the changes in the ground water table and has a certain influence on this process. Since the end of the Late Atlantic period the average uplift rate in this area is $2.1 \mathrm{~mm}$ per year. 